\title{
JOURNAL
}

of Health Inequalities

\section{Unsaturated fat and cardiovascular health in Poland}

\author{
Kinga Janik-Koncewicz ${ }^{1,2}$, Witold A. Zatoński ${ }^{1,2}$, Aleksandra Herbeć ${ }^{2}$ Katarzyna Zatońska ${ }^{3}$ \\ 'Maria Skłodowska-Curie Memorial Cancer Center and Institute of Oncology, Warsaw, Poland \\ 2Health Promotion Foundation, Nadarzyn, Poland \\ ${ }^{3}$ Wrocław Medical University, Wrocław, Poland
}

\begin{abstract}
The 1990s have seen a rapid transformation in cardiovascular health in Poland, including in morbidity and mortality from coronary heart disease (CHD). The causes of this phenomenon were multifactorial. However, in the case of Poland it has been proposed that perhaps the most important mechanisms were changes in the diet, and particularly in the rapid transformation of the structure of fat consumption between 1980s and 1990s, which were triggered by profound social, political and economic changes. In result of these, the Polish diet begun developing towards a Mediterranean style, and included biologically important changes concerning dietary cardio-protective modifications. Specifically, it has been suggested that initially the countries of Central and Eastern European region, including Poland, had experienced deficiency in polyunsaturated fatty acids, especially alpha-linolenic acid, which was then levelled up in Poland at the beginning of 1990s, and which resulted in cardiovascular transformation. This article outlines the key milestones observed in the transformation of diet in Poland between 1950s and 1990s, and offers an overview of the possible contribution it had on the improvements in CHD.
\end{abstract}

KEY WORDS: Polish diet, dietary transformation, CHD, ALA, fat revolution.

ADDRESS FOR CORRESPONDENCE: Kinga Janik-Koncewicz, Maria Skłodowska-Curie Memorial Cancer Center and Institute of Oncology, 15 B Wawelska St., 02-034 Warsaw, Poland, phone: +48 2257094 01, e-mail: kinga.janik-koncewicz@coi.pl

\section{INTRODUCTION}

One of the most striking health phenomena in Poland in the last 25 years have been changes in incidence and mortality from coronary heart diseases (CHD) in adults, a transformation that has been taking place 20 years later than that observed in Western European countries (Fig. 1). After 30 years of steady increase CHD rates reached a historical pick in 1991. Since 1992 an unexpected rapid and sharp decline in $\mathrm{CHD}$ has been observed, which has continued steadily until the present day. This decline applies equally to both sexes and all adult age groups, concerns inhabitants of both rural and urban areas, all geographical and political regions regardless of education and economic status $[1,2]$. It seems to be universal, but the causes of this phenomenon are likely to be diverse.

Coronary heart disease has been casually linked with many factors. However, it has been suggested that in the case of Poland at the beginning of CHD transformation

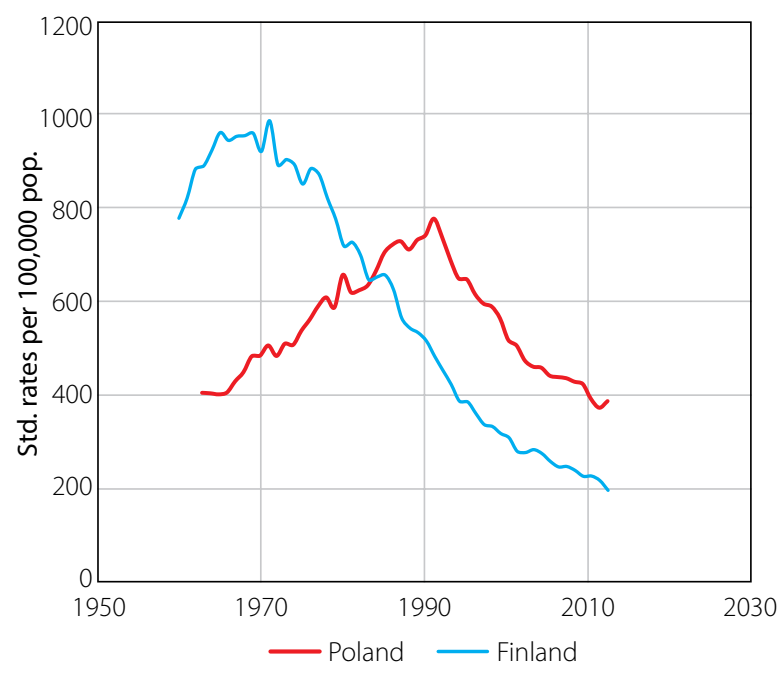

FIG. 1. Cardiovascular disease mortality among men aged 45-64 in Poland and Finland 
the most important and deciding factor (if not the only one) was a change in pattern of fats consumption and levelling out of the deficiency of unsaturated fats [3-5]. This article offers an overview of the key changes in the diet of Poles between 1950s and 1990s, and discusses how the more recent modifications could help to explain the improvements in CHD observed in the wider population.

\section{OVERVIEW OF FOOD PATTERNS IN POLAND 1950s-1980s}

Poland has been experiencing considerable changes in food consumption since the begging of $19^{\text {th }}$ century. Traditionally, the food pattern in Poland was common to the diet typical for a developing rural country. Food rations included domestic food products typical for Central and North European geographical zone, especially animal products (red meat, fats, milk and eggs) and high-starchy products (bread made of white flour and potatoes) [6]. After World War II these changes concerned mainly increasing food availability, with the calorie intake increasing substantially until the end of 1980s. Over the years, agricultural production was increasing and the consumption of almost all food commodities was growing steadily until the beginning of 1980s, except for potatoes and cereals of which consumption showed a decreasing trend [7].

As Poland did not participate in global market then, the range of consumed food products was limited to domestic commodities that were feasible to grow and produce in Poland's particular climate zone and agricultural tradition. Polish diet was therefore characterised by seasonal availability of fruits and vegetable, as well as an increasing consumption of animal products, especially red meat (pork and bovine), fats, milk and dairy products, eggs, and sugar [8].

In the end of 1980s, an average Pole consumed $26 \mathrm{~kg}$ of fats [9]. Fats were substantial food products, especially in rural area, sometimes more valued than meat, and their consumption was increasing with an improving economic situation [10]. At the end of 1970s Poland was one of the countries with the highest animal fat intake. In 1980 s $28 \%$ of animal fats consumed were tissue fats, $31 \%$ was butter and $41 \%$ was cream [7]. Among countries of Central and Eastern Europe only in Hungary a higher consumption of animal fats was observed than in Poland in the same time period: in $198028.7 \mathrm{~kg} / \mathrm{cap}$ ita in Poland (the highest level ever) vs. $29.7 \mathrm{~kg} / \mathrm{capita}$ in Hungary. Since early 1960s until the end of 1980s the intake of butter in Poland has increased almost twice and averaged $9 \mathrm{~kg} /$ capita. This pattern was in contrast to that observed in several Western European countries like Finland, Denmark, Ireland or UK, where trends had a decreasing direction [7].

Vegetable oil consumption was lower during this period and in the end of $1980 \mathrm{~s}$ averaged $7 \mathrm{~kg} /$ capita.
Main vegetable oils consumed in Poland this time was soybean, sunflowerseed and rapeseed oils, with the latter constituting more than $50 \%$ of all vegetable oils consumed [7]. This breakdown in oil consumption was very important, as unfortunately until the end of 1980s the rapeseed oil had high content of toxic erucid acid and glucosinolates and was not beneficial for health [11].

\section{TRANSFORMATION OF POLISH DIET IN THE END OF 1980s AND 1990s}

Since the end of 1980s, Poland began the political and economic transformation leading to emergence of capitalist economy and switching its trade orientation towards western markets. Reforms included, among others, removal of government control over food prices and radical reduction in food and subsidies [8]. In result, prices of animal foods increased dramatically while the cost of plant foods stayed relatively lower. The Polish market begun to participate in global market, and some of the previously closed food markets now experienced revival. Western food products begun to come in large amounts onto the Polish market. Soon after new technologies of food production were introduced from the West [12]. The resulting revolution in prices, broadening of the assortment of food products, and permanent availability of food led to extensive change in structure of food patterns. Overall, consumption of foods of vegetable origin increased (except for sugar) in contrast to animal products [8].

\section{REPLACEMENT OF SATURATED FATS (ANIMAL FAT) BY UNSATURATED FAT (VEGETABLE OILS)}

The period between the end of 1980s and 1995 was time of the most dramatic changes in food patterns and fat revolution. Animal fats consumption decreased by $46 \%$ during this period [7]. It was mainly caused by a sudden decline in butter intake from $9 \mathrm{~kg} /$ capita in 1989 to $3.9 \mathrm{~kg} /$ capita in 1994, and in cream from $8 \mathrm{~kg} /$ capita in 1989 to $3 \mathrm{~kg} / \mathrm{capita}$ in 1995 [7]. Conversely, consumption of vegetable oils increased. Since the level of total fat intake remained stable, animal fats were replaced by fats of vegetal origin. The part replacement of animal fats with vegetable fats is shown on Fig. 2 and well demonstrated by the ratio of polyunsaturated to saturated fatty acids (P : S) ratio which increased by $64 \%$ between 1990 and 1996 in Poland (see Nutrition and public health, pp. 61-62). Consumption of soybean oil increased from 0.4 to $2.8 \mathrm{~kg} /$ capita between 1990 and 1994. Rapeseed oil intake went up from $4.9 \mathrm{~kg} / \mathrm{capita}$ to $7.4 \mathrm{~kg} / \mathrm{capita}$ in 1995 and it was used as a main substrate to produce margarines [7]. New type of soft and easy-spread margarines were introduced on the Polish market at the end of 1980s. They were produced according to Western European technologies and promoted by intensive advertisement campaigns. They were substan- 
tially cheaper than butter. Additionally, since 1990s only a double modified rape begun to be planted in Poland, with likely positive health benefit [11]. Oil from this type of rape seeds has very low content of erucid acid and glucosinolates. It has extremely beneficial for health composition of fatty acids with high proportion of polyunsaturated fatty acids, especially n-3 alpha-linolenic acid (ALA). Soybean oil, rapeseed oil and flaxseed oil are particularly rich in linolenic acid. In addition to the vegetable source, the longest chain n-3 fatty acids (eicosapentaenoic and docosahexaenoic acids) are found in fish oil, and they can also be obtained through metabolic conversion from alpha-linolenic acid [13, 14]. However, consumption of fish in Poland has been maintained at the same level of approx. $10 \mathrm{~kg} / \mathrm{capita} /$ year since 1990 [7]. Therefore, only vegetable oils were significant sources of ALA in the Polish diet.

\section{IMPORTANCE AND ROLE OF ALPHA-LINOLENIC ACID}

Alpha-linolenic acid is an essential dietary fatty acid and it cannot be synthetized in humans, and thus it has to be delivered with diet in adequate amounts. Existing evidence accumulated over many years suggests that linolenic acid is decreasing the risk of cardiovascular disease, particularly deaths from coronary heart disease [15], which was also demonstrated in intervention studies on humans and rodents [16]. This beneficial influence of ALA on cardiac deaths can be caused by antiarrhythmic effects, lowering the level of serum triglycerides, decreasing thrombotic tendency and improving endothelial function [15]. Although results from observational studies are not consistent, most prospective studies suggests existence of an inverse association between ALA intake and fatal coronary heart disease $[15,17]$. Furthermore, it has been suggested that increasing dietary intake of ALA could provide an alternative to fish or fish-oil intake for increasing n-3 long chain polyunsaturated fatty acids status in humans [18], which could be particularly important for decreasing risk of $\mathrm{CHD}$ in populations with low consumption of fish (as Poland) $[19,20]$.

Furthermore, it seems that the most important for health is the type of vegetable oil consumed (the source of oil) and content of essential polyunsaturated fatty acids. In Poland, the replacement of animal fat for vegetable fat was connected with an especially sharp increase intake of rapeseed oil with high ALA content. Most probably this could have been the cause of the levelling out of the deficiency of this fatty acid, and a decline of CHD burden in Poland [4].

\section{THE IMPACT OF CHANGES IN DIET ON CORONARY HEART DISEASES}

According to available data from the scientific literature, there are arguments that changes in dietary patterns

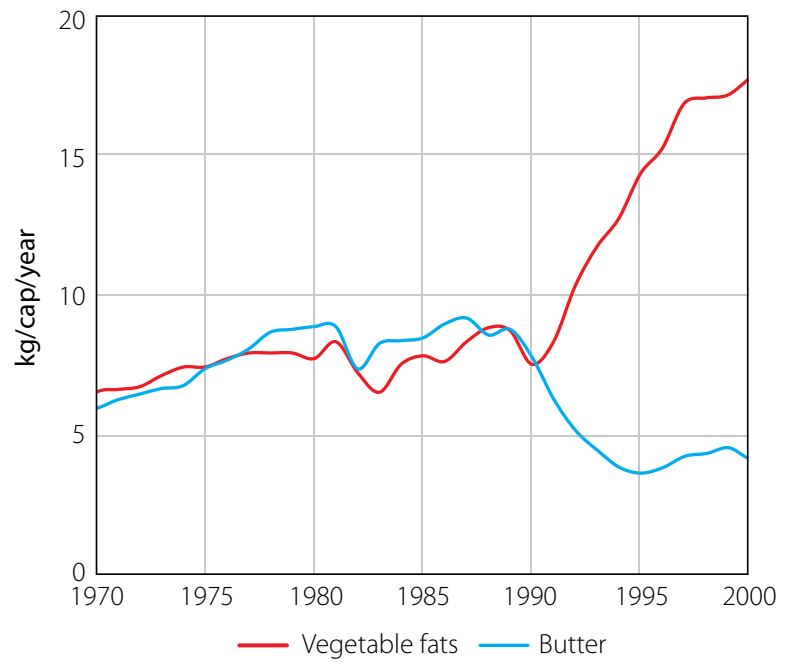

FIG. 2. Vegetable fats and butter intake in Poland, 1970-2000 [data obtained from National Food and Nutrition Institute]

in Poland could be one of the most important factors in changing trends of CHD morbidity and mortality. For example, a careful analysis of different factors (including diet, tobacco, and physical activity) involving a modelling study using data from control trials, meta-analyses, national surveys and official statistics conducted by Professor Zdrojewski and his group from Gdańsk Medical University and other European collaborators [21] points to diet as the most important factor responsible for rapid decrease in mortality from CHD in Poland $[21,22]$. Specifically, $41 \%$ of the decline in men and $33 \%$ in women were attributed to decrease in cholesterol concentration related to a change in structure of fat consumption [21]. Of course, other factors were also involved in changing CHD burden in Poland in 1990s, including tobacco smoking, vodka binge drinking, but also availability and progress in CHD medical services, which have begun to develop in Poland rapidly only at the beginning of $21^{\text {st }}$ century, especially following the accession to the European Union. These topics are beyond the scope of the present manuscript, but readers are encouraged to consult other publications [1,21-24].

\section{DISCLOSURE}

Authors report no conflict of interest.

\section{References}

1. Zatoński W and the HEM project team. Closing the health gap in European Union. Cancer Center and Institute, Warsaw 2008.

2. Zatonski WA, Bhala N. Changing trends of diseases in Eastern Europe: closing the gap. Public Health 2012; 126: 248-252.

3. Zatonski WA, McMichael AJ, Powles JW. Ecological study of reasons for sharp decline in mortality from ischaemic heart disease in Poland since 1991. BMJ 1998; 316: 1047-1051.

4. Zatonski WA, Willett W. Changes in dietary fat and declining coronary heart disease in Poland: population based study. BMJ 2005; 331: 187-188. 
5. Zatonski W, Campos H, Willett W. Rapid declines in coronary heart disease mortality in Eastern Europe are associated with increased consumption of oils rich in alpha-linolenic acid. Eur J Epidemiol 2008; 23: 3-10.

6. Budzyński FW. Transformation and food consumption prognoses. Polish Scientific Publishers, Warsaw 1975.

7. Food and Agriculture Organization of the United Nations. FAOSTAT. Food balance sheets, 2015. Available from: http:// faostat. fao.org (accessed: September 2015).

8. Sekuła W, Babinska K, Petrova S. Nutrition Policies in Central and Eastern Europe. Nutr Rev 1997; 55: S58-S73.

9. Sekuła W, Niedziałek Z, Figurska K, et al. Spożycie żywności w Polsce w latach 1950-1996 w przeliczeniu na energię i składniki odżywcze [Food consumption in Poland converted into energy and nutrients, 1950-1996]. National Food and Nutrition Institute, Warsaw 1997.

10. Narojek L. Charakterystyka zmian w spożyciu tłuszczów wydzielonych w Polsce [Characteristics of changes in fat consumption in Poland]. Human Nutrition and Metabolism 1997; 24: 64-73.

11. Krygier K. Współczesne tłuszcze jadalne [Modern edible fats]. Przemysł Spożywczy 1997; 4: 11-13.

12. Zatoński W. Rozwój sytuacji zdrowotnej w Polsce po roku 1988 [Health development in Poland after 1988]. Cancer Center and Institute, Warsaw 1996.

13. Goyens PL, Spilker ME, Zock PL, et al. Conversion of alphalinolenic acid in humans is influenced by the absolute amounts of alpha-linolenic acid and linoleic acid in the diet and not by their ratio. Am J Clin Nutr 2006; 84: 44-53.

14. Burdge G. Alpha-linolenic acid metabolism in men and women: nutritional and biological implications. Curr Opin Clin Nutr Metab Care 2004; 7: 137-144.

15. Langella JP (ed.). Nutrition and diet research progress. Saturated fats. Metabolism, disease risk and public awareness. NOVA Science Publisher Inc., New York 2012.

16. Lanzmann-Petithory D. Alpha-linolenic acid and cardiovascular diseases. J Nutr Health Aging 2000; 5: 179-183.

17. Mozaffarian D. Does alpha-linolenic acid intake reduce the risk of coronary heart disease? A review of the evidence. Altern Ther Health Med 2005; 11: 24-30.

18. Wood KE, Mantzioris E, Gibson RA, et al. The effect of modifying dietary LA and ALA intakes on omega-3 long chain polyunsaturated fatty acid (n-3 LCPUFA) status in human adults: A systematic review and commentary. Prostaglandins Leukot Essent Fatty Acids 2015; 95: 47-55.

19. Baylin A, Kabagambe EK, Ascherio A, et al. Adipose tissue alpha-linolenic acid and nonfatal acute myocardial infarction in Costa Rica. Circulation 2003; 107: 1586-1591.

20. Mozzafarian D, Ascherio A, Hu FB, et al. Interplay between different polyunsaturated fatty acids and risk of coronary heart disease in men. Circulation 2005; 111: 157-164.

21. Bandosz P, O'Flaherty M, Drygas W, et al. Decline in mortality from coronary heart disease in Poland after socioeconomic transformation: modelling study. BMJ 2012; 344: d8136.

22. Bandosz P, Aspelund T, Basak P, et al. OP72 EUROHEART II-comparing policies to reduce future coronary heart disease mortality in nine European countries: modelling study. J Epidemiol Community Health 2014; 68 (Suppl 1): A36.

23. Petrova S, Dimitrov P, Willett WC, et al. The global availability of n-3 fatty acids. Public Health Nutr 2011; 14: 1157-1164.

24. Zatońska K, Campos H, Ilow R, Janik-Koncewicz K, Różańska D, Regulska-Ilow B, Połtyn-Zaradna K, Szuba A, Zatoński WA. Dietary intake and adipose tissue level of specific fatty acids in a selected group from the Lower Silesia population. Ann Agric Environ Med 2012; 19: 389-394. 